\title{
COMPARATIVE STUDY OF PLATELET COUNT IN NORMAL PREGNANT WOMAN AND IN PREGNANCY- INDUCED HYPERTENSION
}

\author{
Aruna Singh ${ }^{1}$, Brijesh Singh ${ }^{2}$, Arun Kumar Patel ${ }^{3}$ \\ ${ }^{1}$ Associate Professor, Department of Physiology, S. S. Medical College, Rewa, Madhya Pradesh, India. \\ ${ }^{2}$ Associate Professor, Department of Surgery, S. S. Medical College, Rewa, Madhya Pradesh, India. \\ 3 Professor, Department of ENT, Jhalawar Medical College, Jhalawar, Rajasthan, India.
}

\section{BACKGROUND}

ABSTRACT

Pregnancy-induced hypertension is one of the most common and potential life-threatening complications of pregnancy. The aim of this study is to investigate the difference in platelet count in normal pregnant woman and pregnancy-induced hypertension patient.

\section{MATERIALS AND METHODS}

It is a case control study. This study includes 100 cases in which there are two groups. First group has 50 normal pregnant women as control and second group has 50 cases with pregnancy-induced hypertension, in which the subgroup has 40 cases with mild pregnancy-induced hypertension and 10 cases with severe pregnancy-induced hypertension. Study was conducted in the Department of Physiology in collaboration with Department of Obstetrics and Gynaecology in Kamala Raja Hospital (Gwalior). Patients were studied, and platelet count was done in all cases in third trimester of pregnancy from April 2005 to Oct. 2006.

\section{RESULTS}

In this study, there is an inverse relationship between the severity of PIH and platelet count. Mean platelet count was found to be less in patients with higher blood pressure.

\section{CONCLUSION}

Our study and result showed that assay of platelet can be considered as one of the prognostic tools in management of hypertensive disorders of pregnancy.

\section{KEY WORDS}

Platelet Count, Pregnancy, Hypertension.

HOW TO CITE THIS ARTICLE: Singh A, Singh B, Patel AK. Comparative study of platelet count in normal pregnant woman and in pregnancy-induced hypertension. J. Evolution Med. Dent. Sci. 2018;7(27):3138-3140, DOI: 10.14260/jemds/2018/705

\section{BACKGROUND}

Pregnancy-Induced Hypertension (PIH) is one of the most common and potentially life-threatening complication of pregnancy. It affects 5 - 8\% of all pregnancies and is one of the leading causes of high morbidity for both mother and foetus, especially in developing countries.(1) Thrombocytopenia can be due to idiopathic thrombocytopenic purpura (ITP), which is caused mostly because of the formation of autoimmune antibodies, Letsky and Greaves.(2) Pregnancy-induced hypertension (blood pressure greater than 140/90) occurs before or after 20 weeks of gestation with no proteinuria. The clinical manifestations of maternal preeclampsia are hypertension and proteinuria, with or without coexisting systemic abnormalities involving the kidneys, liver or blood. HELLP syndrome is a severe form of preeclampsia and involves haemolytic anaemia, elevated liver function tests (LFTs) and low platelet count.(3) The aim of this study was to investigate the effect of platelet count in pregnancy-induced hypertension.

'Financial or Other Competing Interest': None.

Submission 05-06-2018, Peer Review 20-06-2018,

Acceptance 22-06-2018, Published 02-07-2018.

Corresponding Author:

Dr. Aruna Singh,

MIG-18, Housing Board Colony,

Bodabag, Rewa, Madhya Pradesh, India.

E-mail: drarunassmc@gmail.com

DOI: $10.14260 /$ jemds $/ 2018 / 705$

\section{(c) $(1)$}

\section{Aims and Objectives}

To investigate the difference in platelet count in normal pregnant woman and pregnancy-induced hypertension patient.

\section{MATERIALS AND METHODS Study Area}

It is a case control study. Study was conducted in the Department of Physiology in collaboration with Obstetrics and Gynaecology in Kamala Raja Hospital (Gwalior) were studied and platelet count was done in all cases in third trimester of pregnancy from April 2005 to Oct. 2006. Two millilitres of blood sample were drawn aseptically using the S-Monovette vacutainer blood collection system (Sarstedt, Numbrecht, Germany) from the median antecubital vein of all the subjects and control participants into EDTAanticoagulated tubes. The blood was diluted with the diluent (1\%) ammonium oxalate by 1 in 20 dilutions $(0.02 \mathrm{~mL}$ of blood and $0.38 \mathrm{~mL}$ of diluent). Platelets were counted using improved Neubauer ruled counting chamber (Hawksley, UK) and the number of platelets per litre of blood was calculated using the first principle.

\section{Sample Size}

Present study was carried out in 100 cases, which was conducted on two groups of pregnant women-

Group 1- Control: 50 normal pregnant women.

Group 2- 50 pregnant women (PIH), which was further divided into subgroups of mild PIH and severe PIH. 
a. Mild PIH- Is defined by hypertension (blood pressure greater than $140 \mathrm{mmHg}$ systolic or $90 \mathrm{mmHg}$ diastolic) associated with proteinuria $>0.3 \mathrm{~g} / \mathrm{L}$ in a 24-hour urine collection of $1+$ dipstick or greater in random urine collection after 20 weeks of gestation in a previously normotensive woman. ${ }^{(4)}$

b. Severe PIH- This condition was categorised if systolic blood pressure was $>160 \mathrm{mmHg}$ and diastolic blood pressure was $>110 \mathrm{mmHg}$. (5)

\section{Inclusion Criteria}

All consenting adult ( $>18$ years) pregnant women who were confirmed to have pregnancy-induced hypertension by an obstetrician constituted the subjects for these subjects.

\section{Exclusion Criteria}

Non-consenting, non-adult pregnant women with other pregnancy-related complications were excluded.

\section{Statistical Analysis}

The results were analysed statistically to draw comparison between the groups. The statistical data was processed using Microsoft Excel to draw the values of significance for Group II and its subgroups. Tests of significance applied were ' $\mathrm{Z}$ ' test for statistical analysis to suggest the relation between the observed abnormal value of chosen laboratory tests in the study with hypertensive disorders of pregnancy and its importance in antenatal care.

\section{RESULTS}

\begin{tabular}{|c|c|c|}
\hline Sl. No. & Group & No. of Case \\
\hline 1 & Normal Pregnant & 50 \\
\hline 2 & Pregnancy with PIH & 50 \\
\hline \multicolumn{2}{|c|}{ Table 1. Distribution of Cases } \\
\hline
\end{tabular}

\begin{tabular}{|c|c|c|c|}
\hline Sl. No. & Group & No. of Case & Percentage \\
\hline 1. & Mild PIH & 40 & $80 \%$ \\
\hline 2. & Severe PIH & 10 & $20 \%$ \\
\hline \multicolumn{3}{|c|}{ Table 2. No. and Percentage of Cases of } \\
Pregnancy-Induced Hypertension \\
\hline
\end{tabular}

\begin{tabular}{|l|c|c|c|c|}
\hline $\begin{array}{c}\text { Sl. } \\
\text { No. }\end{array}$ & Platelet Count & $\begin{array}{c}\text { Pregnant } \\
\text { Control }\end{array}$ & Mild PIH & $\begin{array}{c}\text { Severe } \\
\text { PIH }\end{array}$ \\
\hline 1. & $\begin{array}{c}\text { Normal } \\
(1.5-4 \text { lac/cumm })\end{array}$ & $48(96 \%)$ & $35(87.5 \%)$ & $1(10 \%)$ \\
\hline 2. & $\begin{array}{c}\text { Low } \\
(1-1.5 \mathrm{lac} / \mathrm{cumm})\end{array}$ & $2(4 \%)$ & $5(12.5 \%)$ & $9(90 \%)$ \\
\hline 3. & $\begin{array}{c}\text { Very low } \\
(<\mathrm{lac} / \text { cumm })\end{array}$ & $0(0 \%)$ & $0(0 \%)$ & $0(0 \%)$ \\
\hline
\end{tabular}

Table 3. Compression of No. and Percentage of Cases with Normal, Low, Very Low, Platelet Count in Control and Study Group

\begin{tabular}{|c|c|c|c|c|}
\hline $\begin{array}{c}\text { Sl. } \\
\text { No. }\end{array}$ & Platelet Count & $\begin{array}{c}\text { Normal } \\
\text { Pregnant }\end{array}$ & Mild PIH & $\begin{array}{c}\text { Severe } \\
\text { PIH }\end{array}$ \\
\hline 1 & $\begin{array}{c}\text { Platelet count } \\
\text { lacs/cumm) }\end{array}$ & $\begin{array}{c}2.1 \\
\text { lacs/cumm }\end{array}$ & $\begin{array}{c}1.9 \\
\text { lacs/cumm }\end{array}$ & $\begin{array}{c}1.4 \\
\text { lacs/cumm }\end{array}$ \\
\hline \multicolumn{4}{|c|}{ Table 4. Comparison of Mean Platelet Count between } \\
Control, Mild PIH and Severe PIH
\end{tabular}

\begin{tabular}{|c|c|c|c|}
\hline \multicolumn{2}{|c|}{ Normotensive } & \multicolumn{2}{|c|}{ Mild PIH } \\
\hline $\begin{array}{c}\text { Sample Size } \\
N_{1}\end{array}$ & $=50$ & $\begin{array}{c}\text { Sample size } \\
\mathrm{N}_{2}\end{array}$ & $=40$ \\
\hline $\begin{array}{c}\text { Mean platelet } \\
\text { count } \\
\text { (lacs/cumm) }\end{array}$ & 2.1 lacs/cumm & $\begin{array}{c}\text { Mean platelet } \\
\text { count } \\
\text { (lacs/cumm) }\end{array}$ & 1.9 lacs/cumm \\
\hline SD & .445 & SD & .331 \\
\hline
\end{tabular}

SE $(d)=.081$ by applying Z-test $>2$, hence it is significant .

\begin{tabular}{|c|c|c|c|}
\hline \multicolumn{2}{|c|}{ Normotensive } & \multicolumn{2}{c|}{ Mild PIH } \\
\hline $\begin{array}{c}\text { Sample Size } \\
\mathbf{N}_{\mathbf{1}}\end{array}$ & $\mathbf{5} \mathbf{5 0}$ & $\begin{array}{c}\text { Sample Size } \\
\mathbf{N}_{\mathbf{2}}\end{array}$ & $\mathbf{1 0}$ \\
\hline $\begin{array}{c}\text { Mean platelet } \\
\text { count } \\
\text { (lacs/cumm) }\end{array}$ & 2.1 lacs/cumm & $\begin{array}{c}\text { Mean platelet } \\
\text { count } \\
\text { (lacs/cumm) }\end{array}$ & 1.4 lacs/cumm \\
\hline SD & .445 & \multicolumn{3}{|c|}{ SD } & .365 \\
\hline 2. Normotensive verses Severe PIH in Platelet Count \\
\hline
\end{tabular}

SE $(d)=.132$ by applying Z-test $>2$, hence it is significant.

\begin{tabular}{|c|c|c|c|}
\hline \multicolumn{2}{|c|}{ Mild PIH } & \multicolumn{2}{c|}{ Severe PIH } \\
\hline Sample Size N1 & $\mathbf{= 4 0}$ & Sample Size N2 & $\mathbf{= 1 0}$ \\
\hline $\begin{array}{c}\text { Mean platelet } \\
\text { count } \\
\text { (lacs/cumm) }\end{array}$ & $\begin{array}{c}1.9 \text { lacs/ } \\
\text { cumm }\end{array}$ & $\begin{array}{c}\text { Mean platelet } \\
\text { count } \\
\text { (lacs/cumm) }\end{array}$ & $\begin{array}{c}1.4 \text { lacs/ } \\
\text { cumm }\end{array}$ \\
\hline SD & .331 & SD & .365 \\
\hline 3. Mild PIH verses Severe PIH in Platelet Count \\
\hline
\end{tabular}

SE $(d)=.125$ by applying Z-test $>2$, hence it is significant.

\section{DISCUSSION}

In this study we investigated the platelet count of 100 pregnant women, in which we have 50 cases as normal pregnant and 50 with pregnancy-induced hypertension. We observed a significantly lower platelet count among pregnant women with PIH compared to controls. There seems a significant relationship between low platelet count and PIH. Our finding is consistent with findings from previous study,(6) which observed a low platelet count among PIH patients.

Redman et al reported decreased platelet count in women who developed pre-eclampsia and stated that increased platelet consumption is an early feature of this disorder.(7)

Galton et al claimed that the severity of thrombocytopenia correlates with severity of hypertension. ${ }^{(8)}$

Romero et al reported that women with pre-eclampsia and thrombocytopenia have higher incidence of maternal and neonatal complications. $(9)$

In the present study, the mean platelet count falls with increased severity of disease and the count was found to be less in patients with higher blood pressure.

Lower the platelet count, greater the maternal and foetal morbidity and mortality. (Verhaeghe and colleague, 1991 Ledue and co-worker, 1992). 


\begin{tabular}{|c|c|c|c|}
\hline Studies & $\begin{array}{c}\text { Normal } \\
\text { Pregnant }\end{array}$ & $\begin{array}{c}\text { Mild } \\
\text { PIH }\end{array}$ & $\begin{array}{c}\text { Severe } \\
\text { PIH }\end{array}$ \\
\hline & (Count in lacs/cumm of Blood) \\
\hline $\begin{array}{c}\text { (10)Dube and } \\
\text { Associates (1975) }\end{array}$ & 2.3 & 1.9 & 1.9 \\
\hline $\begin{array}{c}\text { (11)Agrawal and } \\
\text { Buradkar (1978) }\end{array}$ & 2.4 & 2.1 & 2.1 \\
\hline (12)Inglis (1982) & 2.6 & 2.4 & 2.1 \\
\hline $\begin{array}{c}\text { (13)Kulkarni and } \\
\text { Suteria (1983) }\end{array}$ & 2.5 & 1.84 & 1.9 \\
\hline (14)Katz (1990) & 2.1 & 1.2 & 1.2 \\
\hline (7)Our Study & 2.1 & 1.9 & 1.4 \\
\hline \multicolumn{4}{|c|}{ Comparison of Mean Platelet Count in different Studies } \\
\hline
\end{tabular}

\section{CONCLUSION}

The platelet count has an association at prediction of increasing grade of PIH. There is an inverse relationship between the severity of PIH and platelet count.

There is definite statistical difference in values of platelet count, platelet count in PIH groups when compared with normotensive pregnant woman. Therefore, these tests may be considered as screening tests to be routinely performed in antenatal workup of women with PIH. Hence, platelet count can be used as a prognostic indicator in pregnancy-induced hypertension.

\section{REFERENCES}

[1] Vanderjagt DJ, Patel RJ, El-Nafaty AU, et al. Highdensity lipoprotein and homocysteine levels correlate inversely in pre-eclamptic woman in northern Nigeria. Acta Obstet Gynecol Scand 2004;83(6):536-42.

[2] Letsky EA, Greaves M. Guidelines on the investigation and management of thrombocytopenia in pregnancy and neonatal alloimmune thrombocytopenia. Maternal and Neonatal Haemostasis Working Party of the Haemostasis and Thrombosis Task Force of the British Society for Haematology. $\mathrm{Br} \quad \mathrm{J}$ Haematol 1996;95(1):21-6.

[3] Steegers EA, von Dadelszen P, Duvekot JJ, et al. Preeclampsia. The Lancet 2010;376(9741):631-44.
[4] NHBPEP (National High Blood Pressure Education Program) Working group report on high blood pressure in pregnancy. NIH Publication No. 00-3029. Revised 2000:1-38.

[5] Davies JR, Fernando R, Hallworth SP. Hemostatic function in healthy pregnant and pre-eclamptic women: an assessment using the platelet function analyzer (PFA-100) and thromboelastograph. Anesth Analg 2007;104(2):416-20.

[6] Jaremo P, Lindahl LT, Lennnmarken C, et al. The use of platelet density and volume measurements to estimate the severity of pre-eclampsia. Eur J Clin Invest 2000;30(12):1113-8.

[7] Redman CW, Bonnar J, Beilin L. Early platelet consumption in pre-eclampsia. $\mathrm{Br}$ Med J 1978;1(6111):467-9.

[8] Galton M, Merritt K, Beller FK. Coagulation studies on the peripheral circulation of patients with toxemia of pregnancy: a study for the evaluation of disseminated intravascular coagulation in toxemia. J Reprod Med 1971;6(2):78-89.

[9] Romero R, Mazor M, Lockwood CJ, et al. Clinical significance, prevalence and natural history of thrombocytopenia in pregnancy-induced hypertension. Am J Perinatol 1989;6(1):32-8.

[10] Dube B, Bhattacharya S, Dube RK. Blood coagulation profile in Indian patients with pre-enclampasia and eclampsia. Br J Obstet \& Gynaecol 1975;82(1):35-9.

[11] Agrawal S, Buradkar S. Coagulation studies in toxemia of pregnancy. J Obstet \& Gynecol Ind 1978;27:992-6.

[12] Giles C, Inglis TC. Thrombocytopenia and macrothrombocytosis in gestational hypertension. Br J Obstet \& Gynaecol 1981;88(11):1115-9.

[13] Kulkarni RD, Sutaria UD. Platelet counts in toxemia of pregnancy. J Obstet \& Gynaecol of India 1983;33:3215.

[14] Katz VL, Thorp JM Jr, Rozas L, et al. Natural history of thrombocytopenia associated with pre-eclampsia. Am J Obstet \& Gynaecol 1990;163(4 Pt 1):1142-3. 